\title{
Research on the Application of National Music Thinking in Solfeggio and Ear Training
}

\author{
Lijuan Yu
}

Shangluo University, Shangluo Shaanxi, 726000, China

Keywords: National music thinking, Solfeggio and ear training, Application.

\begin{abstract}
Solfeggio teaching is a basic course in music learning to help students master more musical skills. With national music being an important part of the development of music in China, it is helpful to cultivate and improve students' music thinking by correctly applying the thinking of national music in the teaching of solfeggio and ear training, which is also an effective way for Chinese music to prosper and develop on the world stage. This paper analyzes the current situation of the solfeggio teaching in China, explores the characteristics of national music thinking, and on this basis, probes into the application of national music thinking in solfeggio and ear training.
\end{abstract}

\section{Introduction}

China's subject of solfeggio and ear training were gradually formed and developed in the collision of Chinese and Western cultures. With the continuous integration and osmosis of Chinese and Western cultures and subject cultures, many problems have arisen in China's solfeggio and ear training. Solfeggio is a basic course in music science, whose main function is to cultivate and improve students' practical music skills. With the development of multiculturalism, the importance of national music thinking in solfeggio teaching is becoming increasingly obvious. Lu Xun said: " Only things that are national in style will be accepted internationally. " To promote the prosperity and development of China's national music on the world stage, we must attach importance to the cultivation of national musical thinking in the teaching of solfeggio and ear training.

\section{Characteristics of national music thinking}

\subsection{Linear thinking}

Due to the different social background and geographical environment, each ethnic group developed their own unique thinking mode and personality, and gradually formed their music thinking over the long course of history. Linear thinking is one of the most representative features of China's national music, while characteristics of Western music are mostly spatial, which is also the biggest difference between eastern and Western national musical thinking. Erhu masterpieces The Moon Over a Fountain and the suona masterpieces Hundreds of Birds Worshipping the Phoenix are typical examples of linear thinking works. These works are always in imitation of nature with beautiful melodious tunes, thus usually requires one single musical instrument to express. On the other hand, works of Western music pieces such as Pastoral Symphony and New Century Symphony gives a huge magnificent momentum, and feels like listening to all kinds of reverb in impact while standing in the three-dimensional world of a seabed. It can be clearly seen from these musical works that the thinking of China's national music is mainly linear, and that of Western music is mainly three-dimensional and perspective. Linear thinking osmosed all aspects of Chinese aesthetic psychology and has become a kind of consciousness and thinking habit of the Chinese people. Under the influence of linear thinking, Chinese national music is mainly monophonic.

\subsection{Emphasis on irregular expression}

Through studying the music elements of national music, we can see that China's national music 
thinking focuses on irregular and implicit expressions. For example, China's traditional folk songs often have irregular lyrics, which allow singers the free play to show their own personality and talent. Those irregular, implicit expressions fully demonstrated the inclusiveness of China's traditional folk music. National music emphasizes the expression of rubato beat in rhythm, which is obviously different from the regularity and sophistication of Western beats, highlighting the unique tunes and aesthetic taste of China's national culture.

\subsection{National music attaches importance to the creation of artistic conception}

The folk music of China is mostly expressed in the form of swimming lines, attaching importance to the melody of the tune and the smooth flow of lines, thus full of musical flavor. Flute and Drum at Sunset is a folk music piece well-known to China's public, which is expressed in a flowing musical form with guqin, giving a profound artistic conception. In the process of creation, folk music in China often adopts the method of ending merging and heading changing, creating a feeling of familiarity and Déjà vu, and deeply immersing the audience in the mood created by the music.

\subsection{Music structure with a strong ethnic color}

China has long been in a society of agricultural economy and casual, loose lifestyle, and Chinese people's logic thinking is weak, making the traditional music materials in China lacking logic. The development of national music structure is liberalized and diversified. Western music has a higher requirement on the structure, logic and normative systems. The structural features of Chinese folk music make it necessary to emphasize the unity, flavor and style of music in the teaching process, and require more attention to the expression of music content. This feature, structure of music attached to the content, makes China's music pay more attention to lyricism. Such is the strong ethnic colors.

\section{Current status of the application of national music thinking in solfeggio teaching}

Two of the main contents of solfeggio professional teaching are the singing training and auditory training. And the solfeggio teaching process is to train the students to have the ability to read the score and sing. And solfeggio training can improve students 'ability of comprehension and expression of music. National music thinking integrated into solfeggio training can not only effectively improve students' aesthetic listening and singing skills, but also improve their musical literacy. The solfeggio not only possesses the function of music technology cultivation, but also contains a wealth of music culture. However, the application of national music thinking in the process of solfeggio teaching in China is not yet in place.

Solfeggio is a basic course in music major and also a compulsory course in music learning. Solfeggio training gradually formed a fixed system in its long-term development. The system of solfeggio training in China is formed under heavy Western influence. Most of the teaching materials used in the teaching of solfeggio in China are selected according to Western habits seriously affecting the role of China's national music thinking in the solfeggio teaching. In the process of actual teaching, although having the ideas of integrating national music thinking and cultivating students' national music quality, teachers often fail to put them into action for various reasons. The differences between Chinese folk music and Western music in terms of harmony and composition have also made it difficult for students who are accustomed to the method of solfeggio training in Western traditional tonal music to understand the mood of traditional folk music.

The diversified development of culture makes many people prefer foreign cultures and many students are not interested in the study of national musical thinking in solfeggio, and they are not active or enthusiastic in learning. At present, the solfeggio teachers in China generally have the problem of weak national music quality, and their ability to organize national music thinking teaching is not high, which seriously hinders the students' learning and absorption of traditional music thinking knowledge, and the teaching effect is difficult to improve. There are many problems in some colleges and universities solfeggio courses of "national music thinking", such as low number of ethnic music with accompaniment, not attaching importance to the collection of valuable text descriptions to the tracks, rarely conducting musical thinking ability training, which eventually leading to national music 
thinking not playing an effective role in solfeggio training.

The national music culture in China is confronted with the dilemma of no inheritance or development, and modern music teaching cannot play its function of inheriting, developing and promoting the traditional national music culture. It is imperative to integrate national music thinking into the solfeggio teaching. Through pitch, tone, rhythm and style training with unique national characteristics, it helps students to establish national musical feeling in solfeggio training and becoming a new generation with national musical thinking. The cultivation of national musical thinking can also enhance students' music appreciation ability and aesthetic judgement, enable students to develop interest in learning national music, deeply understanding the language structure of the characteristics of our national music, and constantly improving and innovating our national music, and enriching our traditional ethnic music vocabulary system.

\section{The role of national music thinking in solfeggio teaching}

\subsection{Effectively improving the students' sense of rhythm in music}

Rhythm is an important part of music, because mastering the rhythm of music lets the music out of the shackles and assume the meaning of existing alone, thus attention should be directed to the cultivation of the sense of rhythm in solfeggio teaching. Rhythm training should be conducted through the entire music teaching. Rhythm training for students can also exercise students 'ability to master the beat, improve students' memory ability, help students grasp the rhythm of music in accordance with the music memory, and improve their musical rhythm. The national music of China is very flexible for the basic rules of the national music are basically the same, and there is no fixed syllable between the beat. Players in the play, need to find the rhythm according to the specific pause in the lyrics. In solfeggio teaching, conducting national music thinking training among students can greatly improve their ability to master the rhythm and sense of rhythm in music.

\subsection{Enhancing students' solfeggio training}

Solfeggio training is a comprehensive training method, which not only includes pitch training, but also solfeggio practice, so that students have a more comprehensive and profound understanding of music. China's national music is a high-plasticity music form in that with a same track, every singer can sing in their own unique style and according to their own understanding and singing style, at the same time representing China's unique music features.

\subsection{More reasonable classroom training time}

The teaching of solfeggio is formed by the collision and fusion of Chinese and Western culture; however, the content of teaching is mainly based on the thinking and characteristics of Western music and culture. By incorporating national music into the teaching of solfeggio and cultivating the thinking of national music, students can master and understand different forms of music culture and improve learning efficiency. The application of the national music thinking in the solfeggio teaching has provided an opportunity to adjust the solfeggio teaching curriculum where students can learn not only the traditional Chinese music but also the Western music knowledge. In addition, students can build a more complete knowledge system of music skills by comparison.

\subsection{Helps to optimize the music teaching structure}

Professional solfeggio training takes the form of group teaching, and in the choice of textbooks mainly done from the perspective of Western music and culture, which is not conducive to the development of traditional Chinese music. For this reason, the field of music teaching in China has been committed to the reform of teaching materials, adding a lot of excellent national culture, and the new music teaching material makes the process of solfeggio training must be optimized and adjusted. The new music teaching structure gives students full thinking time, which provides convenience for students to learn traditional ethnic music knowledge and cultivate national music thinking. 


\section{Measures to improve the application of national music thinking in the teaching of solfeggio}

\subsection{Reform the music teaching structure and attach importance to the cultivation of students' comprehensive music ability}

Promoting the application of national music thinking in solfeggio teaching is not to exclude Western music thinking. Instead, it is hoped to combine Chinese and Western styles with a two-pronged approach to gain an in-depth and comprehensive understanding of two different musical backgrounds and enhance students' comprehensive ability in music. This requires music teachers to optimize and reform the existing teaching structure, first lay a solid foundation for students to master the use and basic skills of Western style tone, based on this is the inclusion of traditional Chinese music elements, and integrate national music thinking into the solfeggio teaching. In the teaching form, we can employ the teaching mode of combining class teaching and individual tutoring, and respect the differences of students and their demand of individualized development. In practice teaching, students should be left with enough thinking and practicing time.

\subsection{Optimize the team construction of solfeggio teachers, strengthen teacher's national music thinking learning}

Teachers 'mastery of national music thinking and teaching skills also influence the application of national music thinking in the teaching of solfeggio, as well as national music thinking's function of improvement of students' mastery of music skills. The quality of teachers is the key factor to improve the teaching efficiency, and constructing a teaching staff that can skillfully apply the thinking of national music in the teaching of solfeggio is a common concern in the field of music education at present. Teachers should be wanting to use the national music thinking to improve students' music skills, and they must first have a higher national musical literacy. Teachers themselves have a stronger musical foundation, the ability to accept music knowledge, and music knowledge framework than the students, therefore, the music colleges and universities can continuously strengthen the instillation of folk music knowledge and national music thinking knowledge of solfeggio teachers. The traditional types of musical instruments in China are very rich and internationally acclaimed. However, few music teachers can give a detailed list of traditional Chinese musical instruments. Music institutions can also train teachers by strengthening their learning of traditional musical instruments to boost their national music thinking. With oral teaching being the quickest way to master the essence of national musical, solfeggio teachers should increase participation in folk activities and enjoy more exposure to Chinese folk music.

\subsection{Eliminate students' contradictory psychology of solfeggio learning with national style musicality training}

The solfeggioist can use the dual-musicality training mode. This combination of Chinese and Western training models can complement each other, and experience and perceive the charm of the two forms of music in China and the West. The main content of solfeggio teaching is to cultivate and enhance the students' hearing ability. The dual-musicality training mode can make the national music thinking fully playing the part of cultivating students' pitch, rhythm, tempo and other skills. Dual-musicality training model can greatly enrich the teaching content; the infusion of Chinese and Western cultures can effectively stimulate students' enthusiasm for learning music skills and eliminate students' contradictory psychology of solfeggio learning.

\section{Conclusion}

The application of national musical thinking in the teaching of solfeggio and ear training is conducive for solfeggio and ear music teaching to undertake the mission of inheriting, developing and promoting China's outstanding national music and culture. Solfeggio teaching can help students master the music skills, and integrating the national music thinking into the solfeggio teaching can equip students with national music thinking, improved musicianship and enhanced identification of the national music culture, hence taking the initiative to undertake the responsibility to promote 
China's outstanding national music culture.

\section{References}

[1] Gu Yibai. On national music thinking in solfeggio teaching, Music Times, 2015, (06).

[2] Wang Yu. Yunnan ethnic music works in the solfeggio teaching, Art Education, 2015, (06).

[3] Wang Xin. Analysis of solfeggio teaching of national music thinking, Contemporary Educational Practice and Teaching Research, 2015, (05).

[4] Yan Xiuli, Hu Yifang. On the impact of national music thinking on professional solfeggio teaching, Liaoning Radio and Television University, 2016, (04). 